\title{
The War of Judicial Independence: Letters from the Kansas Front
}

\author{
Richard E. Levy*
}

LETTER 1: LAW LAW LAND

\section{Dear Readers:}

To many observers, ongoing efforts around the country to assert political control over the judiciary have some of the characteristics of war-including innocent civilian casualties. Nationally, the battle to fill Justice Scalia's seat on the United States Supreme Court was fierce. Here in Kansas, political efforts to control the courts, particularly the Kansas Supreme Court, garnered national attention. ${ }^{1}$

Most recently, in the fall 2016 elections, conservative groups mounted a well-financed effort to unseat four Supreme Court justices (Lawton R. Nuss, Carol A. Beier, Dan Biles, and Marla J. Luckert). ${ }^{2}$ The results of the elections in the State of Kansas, however, ran somewhat

* J.B. Smith Distinguished Professor of Constitutional Law, University of Kansas School of Law. I thank the Law Review for the opportunity to publish this essay; Justine Koehle, class of 2017, for valuable research assistance; and Kevin Campbell and Lou Mulligan for helpful comments on earlier drafts. As always, the views expressed in this essay are purely my own; I do not speak on behalf of the law school or the university.

1. See Lincoln Caplan, The Political War Against the Kansas Supreme Court, NEw YORKER (Feb. 5, 2016), http://www.newyorker.com/news/news-desk/the-political-war-against-the-kansassupreme-court; John Eligon, Courts Budget Intensifies Kansas Dispute Over Powers, N.Y. TIMES (June 6, 2015), http://www.nytimes.com/2015/06/07/us/courts-budget-intensifies-kansas-disputeover-powers.html?_r=0; Joe Palazzolo, Kansas Lawmakers' Budget Links Court Funding to Judicial Decision, WALL STREET J. (May 19, 2015), http://www.wsj.com/articles/kansas-lawmakers-budgetmove-links-court-funding-to-court-decisions-1432067876.

2. Governor Sam Brownback was one high-profile contributor to this effort. See Bryan Lowry, Brownback's PAC Gives Thousands to Group Seeking to Oust Justices, WiCHITA EAGLE (Nov. 1, 2016), http://www.kansas.com/news/politics-government/election/article111799967.html. Justice Stegall was also on the retention ballot, because this was the first election following his appointment. Insofar as Justice Stegall was a Brownback appointee and presumed ally, the campaign against the other four justices exempted him. See, e.g., Steve Rose, Attempt to Oust Kansas Supreme Court Judges Is Likely Doomed, KAN. CiTY STAR (June 18, 2016), http://www.kansascity.com/opinion/opn-columns-blogs/steve-rose/article84456322.html ("The single Brownback appointee, Caleb Stegall, who is up for retention, will somehow be differentiated from the others during the ouster campaign"). The impact of the campaign can be assessed by comparing the results for the four targeted justices with the results for Justice Stegall. See infra notes 61-62 and accompanying text. 
counter to national trends. To be sure, the state remained reliably "red," in the sense that Republican candidates swept the presidential and congressional vote, and retained control of statewide offices and both the Kansas House of Representatives and Kansas Senate. ${ }^{3}$ On balance, however, the Kansas government became somewhat less "conservative." A number of the most conservative members of the state legislature were unseated in the primaries or in the general election. ${ }^{5}$ Critically for purposes of this essay, moreover, the four justices targeted by conservatives won their retention elections. ${ }^{6}$

These results may provide a temporary respite from the escalating tensions between the political branches and the judiciary. On the legislative side, there are fewer strident voices attacking the courts or advocating for retaliatory legislation. Conversely, the Kansas Supreme Court is less vulnerable politically. The failure of efforts to unseat the four targeted justices has afforded them a certain measure of job security and suggests that future efforts along similar lines are unlikely to succeed. Nonetheless, tensions are almost certain to flair anew in light of the Kansas Supreme Court's most recent ruling in the adequacy portion of ongoing school finance litigation. ${ }^{7}$

I am grateful to the editors of The University of Kansas Law Review for affording me the opportunity to address these developments. The form of my contribution - as a series of letters to readers - is meant both to evoke a proud tradition of using public letters to address important issues of the day and to afford the opportunity to discuss these matters in

3. See generally 2016 General Election Official Vote Totals, KAN. SECRETARY ST., https://www.sos.ks.gov/elections/16elec/2016_General_Election_Official_Results.pdf (last visited Apr. 1, 2017) [hereinafter 2016 General Election Results].

4. I have placed the term "conservative" in quotation marks because the term seems to mean different things to different people. See, e.g., Conor Friedersdorf, What Americans Mean when They Say They're Conservative, AtlantiC (Jan. 27, 2012), https://www.theatlantic.com/politics/archive/2012/01/what-americans-mean-when-they-say-theyreconservative/252099/. In contemporary political parlance, it generally refers to a political ideology characterized by social policies that reflect traditional moral values on matters of sexuality, marriage, and abortion (often grounded in fundamentalist religious views), and economic policies that oppose regulation, taxation, and government benefit programs. See id. Notwithstanding this general understanding of what it means to be politically conservative, there are many disagreements among conservatives and within the Republican Party on particular issues-just as there are disagreements among progressives/liberals and within the Democratic Party. See id.

5. Tim Carpenter, Election Shifts Legislature to Center-Right on Political Dial, TOPEKA CAP.-J. (Nov. 8, 2016), http://cjonline.com/news/2016-11-08/election-shifts-legislature-center-rightpolitical-dial.

6. 2016 General Election Results, supra note 3, at 12.

7. Gannon v. State (Gannon IV), No. 113,267, 2017 WL 833551, at*41-42 (Kan. Mar. 2, 2017) (upholding lower court finding that funding levels were constitutionally inadequate and giving the legislature until June 30, 2017, to adopt a new formula that cures the constitutional deficiencies). 
a more personal voice. ${ }^{8}$ Insofar as I am writing from a personal perspective, it is best for me to be up front about my biases in these matters: I am in favor of judicial independence. I am in favor of judicial independence because I am in favor of the rule of law, and I believe that judicial independence is essential to preserving the rule of law. Indeed, the most important thing I have to say is that judicial independence is worth fighting for even if - and perhaps especially when-we disagree with the courts' decisions.

As I have explained elsewhere, ${ }^{9}$ the rule of law is the essential foundation of a free and prosperous society. In this context, what I mean by the rule of law is that the state operates pursuant to generally applicable and legally binding rules enacted or adopted through constitutionally prescribed processes that afford them legitimacy. ${ }^{10}$ This means that when the government acts, it must have the legal authority to do so, and that the law operates as a limit on the actions of government officials. History has shown that the rule of law is critical to a system of "ordered liberty" and to the well-being of society. Without the rule of law, individual liberties are not secure, markets cannot function, and concentrated power is unconstrained. People who live in countries that have the rule of law enjoy greater security, prosperity, and liberty. ${ }^{11}$

In our system, the judiciary determines whether the government has complied with the rule of law and thereby ensures the proper functioning of the constitutional order. ${ }^{12}$ Under separation-of-powers principles, the legislature makes the laws, the executive implements the laws, and the courts interpret the laws. This account, to be sure, oversimplifies the separation of powers, because the lines between making, enforcing, and interpreting the laws are far from clear and because the proper balance of authority and responsibility in particular contexts presents a variety of

\footnotetext{
8. For constitutional scholars like me, the prime example of this format is the Federalist Papers. See The Federalist Papers, CONGREss.Gov, https://www.congress.gov/resources/display/content/The+Federalist+Papers (last visited Apr. 1, 2017). Unlike the authors of the Federalist Papers, however, I shall not use a pseudonym.

9. See Richard E. Levy, The Tie That Binds: Some Thoughts About the Rule of Law, Law and Economics, Collective Action Theory, Reciprocity, and Heisenberg's Uncertainty Principle, 56 U. KAN. L. REV. 901, 902-03 (2008).

10. The rule of law also imposes a corresponding duty on the part of citizens to accept the legitimacy of and comply with these "generally applicable and legally binding rules" even when they disagree with the law.

11. See generally Francis Fukuyama, The Origins of Political Order: From Prehuman Times TO THE FRENCH REVOlution, (Reprint Ed. 2012) (discussing the essential conditions for a stable state, including the rule of law).

12. See Marbury v. Madison, 5 U.S. 137, 176-80 (1803). Chief Justice John Marshall famously proclaimed in Marbury v. Madison, "[i]t is emphatically the province and duty of the judicial department to say what the law is." Id. at 177.
} 
complex issues. Nonetheless, within this constitutional structure, the courts' critical role is to act as independent arbiters of the law, both as a means of fairly resolving legal disputes and of providing an authoritative determination of "what the law is."13

Insofar as the courts are entirely dependent upon the other branches of government for their operation and lack the ability to implement their own orders, their power depends on public acceptance that their decisions represent an authoritative determination of the law. ${ }^{14}$ If courts become little more than instruments of political power, then they lose their legitimacy and can no longer serve their critical functions. Accepting judicial independence and the legitimacy of decisions with which we disagree, however profoundly, is a small price to pay for the benefits of the rule of law.

\section{LETTER 2: A SERIES OF ESCALATING EVENTS}

Dear Readers:

It is not always easy to pinpoint exactly when a war begins-some wars are triggered by dramatic events or sudden attacks, but others build over time, from occasional and isolated skirmishes that gradually escalate into open warfare. It is in the nature of separation of powers that there will be tensions between the political branches and the judiciary, especially when the judiciary exercises the power to invalidate the actions of the legislative and executive branches. ${ }^{15}$ It is also only natural for political actors to want control over the power that the judiciary wields. ${ }^{16}$ So we may expect judicial independence to be a contentious issue and for there to be occasional conflict. These inherent tensions become cause for concern, however, when political actors seek to

\footnotetext{
13. Id.

14. A striking example of this phenomenon was Vice President Al Gore's acceptance of the Supreme Court's decision in Bush v. Gore. 531 U.S. 98, 111 (2000); Al Gore, Vice President, $\begin{array}{lllll}\text { Presidential Concession } & \text { Speech } & \text { (Dec. }\end{array}$ http://www.americanrhetoric.com/speeches/algore2000concessionspeech.html.

15. President Andrew Jackson is reputed to have responded to the Supreme Court decision in Worcester v. Georgia, 31 U.S. 515 (1832), "John Marshall has made his decision, now let him enforce it." Jeffrey Rosen, Supreme Court History: The First Hundred Years, PBS (2006) http://www.pbs.org/wnet/supremecourt/antebellum/history2.html. Whether Jackson actually said it is now a matter of considerable doubt. $I d$.

16. See 1937: Roosevelt Announces “Court-Packing” Plan, History, http://www.history.com/this-day-in-history/roosevelt-announces-court-packing-plan (last visited Apr. 1, 2017). So, for example, Franklin Delano Roosevelt famously responded to Supreme Court decisions invalidating key "New Deal" legislation by proposing the so-called "court-packing" plan, which would have allowed him to appoint six new Justices to the Supreme Court. Id.
} 
subordinate the judiciary, strip the courts of their jurisdiction and powers, or defy judicial orders, thereby threatening judicial independence and the rule of law. ${ }^{17}$

Over the last dozen or so years, conflict between the judiciary and political branches in Kansas intensified as the result of a series of actions and reactions, set against the backdrop of economic turmoil and partisan political polarization. To provide context for the discussion in the letters that follow, I offer the following overview of key developments, presented conceptually and in roughly chronological order:

- School Finance Litigation (Montoy): Although there were certainly conflicts between politicians and the judiciary before then, the origins of the current conflict in Kansas can be traced to the Montoy school finance litigation. ${ }^{18}$ In that case, the Kansas Supreme Court ruled that the legislature had failed to fulfill its constitutional duty under Article VI of the Kansas Constitution to provide suitable funding for public education, and declared that the legislature must provide roughly $\$ 850$ million in additional funding to satisfy this duty. ${ }^{19}$ Because the court's rulings required additional expenditures, many legislators regarded them as a usurpation of the legislature's exclusive power of appropriation. ${ }^{20} \mathrm{~A}$ contentious special legislative session followed, in which

17. This is not to say, however, that political disregard for judicial independence or the rule of law is necessarily or entirely to blame for escalating tensions. Judicial overreach, particularly on highly contentious matters, may invite political retaliation. Thus, whether it is the political branches or the judiciary that starts the war for judicial independence may be entirely in the eye of the beholder.

18. See generally Montoy v. State (Montoy IV), 138 P.3d 755 (Kan. 2006) (concluding that additional funding promised by the legislature satisfied the court's prior orders and dismissing the case); Montoy v. State (Montoy III), 112 P.3d 923 (Kan. 2005) (concluding that legislative response to prior decision failed to cure constitutionally inadequate funding levels); Montoy v. State (Montoy II), 102 P.3d 1160 (Kan. 2005) (per curiam), withdrawn and republished with concurring opinion, 120 P.3d 306 (Kan. 2005) (upholding lower court's findings that legislature failed to fulfill its constitutional duty to provide suitable funding for schools); Montoy v. State (Montoy I), 62 P.3d 228 (Kan. 2003) (reversing lower court's dismissal of the case and remanding for trial on the merits). I have previously offered a detailed analysis of the Montoy litigation. Richard E. Levy, Gunfight at the K-12 Corral: Legislative vs. Judicial Power in the Kansas School Finance Litigation, 54 U. KAN. L. REV. 1021, 1040-106 (2006) [hereinafter Gunfight at the K-12 Corral]. I will not repeat the details here.

19. See Montoy III, 112 P.3d at 940-41 (stating that the legislature must provide additional funding of $\$ 285$ million for the coming year, $\$ 142$ million of which was already provided in previously adopted legislation, and the remaining $\$ 585$ million in the following year).

20. Bryan Lowry, Gov. Sam Brownback's Push to Change Kansas Supreme Court Seen as Linked to School Finance, KAN. CITY STAR (Jan. 24, 2015), http://www.kansascity.com/news/article8071974.html\#!. See KAN. CONST. art. 2, § 24 ("No money shall be drawn from the treasury except in pursuance of a specific appropriation made by law."). 
there was talk of defiance and consideration of constitutional amendments to deprive the court of power. In the end, the legislature grudgingly - under threat of a judicial order closing the schools-promised sufficient funding to satisfy the court. ${ }^{21}$ Although constitutional amendments to curtail the courts' powers failed, the legislature did adopt some statutory changes, including provisions purporting to deny the courts' authority to enjoin funding and thereby close the schools. $^{22}$ More broadly, the confrontation left many in the legislature resentful of the court, and created fertile ground for subsequent measures targeting the courts.

- Intervening Events: Although the resolution of the Montoy litigation eased tensions between the judiciary and political branches somewhat, intervening events set the stage for a renewal of the conflict. First, the "great recession" of 2008 led to economic turmoil and a dramatic downturn in the State's tax revenues. In the face of a budget crisis, the legislature did not appropriate the funding promised in Montoy. ${ }^{23}$ Second, the elections of 2010 and 2012 saw substantial gains by the most conservative elements of the state's Republican Party, which captured many statewide offices, including the governorship. ${ }^{24}$ In the legislature, the traditional balance between the moderate and conservative wing of the Republican Party shifted sharply in favor of the conservative wing, especially after moderates who opposed

21. The legislature passed and the governor signed S.B. 3 during the summer 2005 special session, which was followed by the adoption of S.B. 549 in the 2006 regular session. See Gunfight at the K-12 Corral, supra note 18, at 1046-47 (discussing S.B. 3 and S.B. 549). These bills promised additional appropriations for schools that were sufficient to satisfy the Kansas Supreme Court, which dismissed the case. Montoy IV, 138 P.3d at 762, 765-66. For further detail, see Gunfight at the K-12 Corral, supra note 18, at 1046-47.

22. See KAn. StAT. ANN. § 72-64b03 (Supp. 2016) (providing for the creation of a special three-judge court and specifying that the court "shall not have the authority to order a school district or any attendance center within a school district to be closed or enjoin the use of all statutes related to the distribution of funds for public education"); KAN. STAT. ANN. § 60-2106(d) (Supp. 2016) (specifying that appellate courts "shall not have the authority to order a school district or any attendance center within a school district to be closed or enjoin the use of all statutes related to the distribution of funds for public education"). For further discussion of these provisions, see infra notes 81-94 and accompanying text.

23. See, e.g., Gannon v. State, No. 10C1569, 2013 WL 146092, at*27 (Kan. Dist. Ct. Jan. 10, 2013) (discussing the Legislature's failure to provide funding promised in Montoy litigation as relevant background to the case before the court).

24. Election Statistics, KAN. SECRETARY ST., http://www.kssos.org/elections/elections_statistics.html (last visited Apr. 1, 2017) (providing links to download the results for the 2010 and 2012 statewide elections). 
the conservative agenda were "primaried out" in $2012{ }^{25}$ A central feature of this shift was the enactment of substantial tax cuts, which were the centerpiece of the Governor's economic agenda. Conservatives in the legislature seemed eager to challenge the judiciary, adopting various statutes that defied settled constitutional doctrine. ${ }^{26}$ The legislature also ignored previous legislative promises to provide additional funding for schools, eventually precipitating a new round of school finance litigation. ${ }^{27}$

25. These events are aptly summarized by Joseph A. Aistrup as follows:

In the second year, the centerpiece of Brownback's agenda became a plan to phase out the state's income tax. Over the objections of the President of the Kansas Senate, Republican Steve Morris, Brownback's Republican allies passed the largest tax cut in the state's history, including completely eliminating the state income tax for privately held companies. Morris could not support creating a cumulative $\$ 2$ billion hole in the state's budget by 2017. The combination of this issue and a redistricting battle set into motion an open feud between the governor and the senate president, which ended in a GOP primary battle between moderate incumbent senators and supporters of Morris versus Brownback and Kansas Chamber of Commerce-backed challengers to these incumbents. On a hot August 2012 primary election day, 15 of 21 senate moderates lost, including President Morris.

Joseph A. Aistrup, Kansas Elections: Then and Now, 25 KAN. J.L. \& PUB. POL'Y 301, 302 (2016) (footnotes and citations omitted).

26. See, e.g., Kansas Second Amendment Protection Act, Kan. Stat. AnN. §§ 50-1201 through 50-1211 (Supp. 2016). This statute purports to insulate firearms that were made and sold in the state (and did not move in interstate commerce) from federal regulation. See id. Such a statute is clearly contrary to the Supremacy Clause of the United States Constitution, Article VI, Section 2, insofar as federal power over interstate commerce includes the power to regulate local economic activities if their aggregate effects on interstate commerce are substantial. See Gonzales v. Raich, 545 U.S. 1, 17-33 (2005) (upholding federal power to regulate cultivation of marijuana for personal consumption). Thus, it is not surprising that the act did not prevent prosecution for violation of federal gun laws. See Order Denying Motion, United States v. Cox, No. 15-10150-01,02-JTM, 2017 WL 411358, at *2 (D. Kan. Jan. 31, 2017) ("[T] he Constitution could not be clearer on one point: if the National Firearms Act is a valid exercise of Congressional taxing power, and if it does not infringe on rights granted in the U.S. Constitution, then it is the 'supreme Law of the Land,' regardless of what [the Second Amendment Protection Act] says.").

27. This litigation, which is still pending, has produced a number of published decisions by the Kansas Supreme Court as well as two lengthy opinions by the three-judge panel hearing the case at the trial level. See generally Gannon v. State (Gannon IV), No. 113,267, 2017 WL 833551 (Kan. Mar. 2, 2017) (upholding lower court finding that funding levels were constitutionally inadequate); Gannon v. State (Gannon III), 372 P.3d 1181 (Kan. 2016) (concluding that legislative response had not fully cured inequitable funding in violation of the Kansas Constitution); Gannon v. State (Gannon II), 368 P.3d 1024 (Kan. 2016) (concluding that the state had failed to cure equity deficiencies identified in prior phases of the litigation); Gannon v. State (Gannon I), 319 P.3d 1196 (Kan. 2014) (affirming lower court's finding of inequitable funding but remanding the adequacy challenge because the lower court had not applied the proper standards for determining adequacy); Gannon v. State, No. 2010CV1569, ShawneE CT. (Kan. Dist. Ct. June 26, 2015), $\mathrm{http}: / /$ www.shawneecourt.org/DocumentCenter/View/532 (concluding that the state was no longer in substantial compliance with equity rulings after it failed to implement promised equalization aid); Gannon v. State, No. 2010CV1569, ShawneE CT. (Kan. Dist. Ct. Dec. 30, 2014), http://www.shawneecourt.org/DocumentCenter/View/527 (reaffirming prior finding that the state 
- Legislative Actions Targeting the Judiciary: With the legislature and governor's office fully controlled by staunch conservatives, various initiatives targeting the courts were introduced, with varying degrees of success. ${ }^{28}$ One point of emphasis for conservatives was changing the means of judicial selection from the use of nominating commissions, so as to give the Governor and his allies in the Senate the ability to pick conservative judges. ${ }^{29}$ With respect to the courts of appeal, this sort of change was accomplished by statute in $2013,{ }^{30}$ but changing the means of selecting Kansas Supreme Court justices would require a constitutional amendment, and the proponents of this change were unable

provided inadequate funding after applying correct standards on remand); Gannon v. State, No. 10C1569, 2013 WL 146092 (Kan. Dist. Ct. 2013) (original lower court decision finding that school finance was constitutionally deficient because it was inadequate and inequitable); see also Gannon v. State, 357 P.3d 873, 874 (Kan. 2015) (affirming three-judge panel's denial of school district's motion to intervene). For further discussion of Gannon and its implications, see infra notes 36-38, 82-101, and 113-28 and accompanying text.

28. In addition to the actions discussed in the following text, numerous other measures, including constitutional amendments limiting judicial power, were introduced but did not pass. In the 2016 session, for example, S.B. 439 purported to define impeachable offenses that would allow the removal of judges to include "attempting to usurp the power of the legislative or executive branch of government.” S.B. 439, 2016 Leg. Sess. § 1(h) (Kan. 2016) (as amended by the Senate Committee of the Whole), http://www.kslegislature.org/li_2016/b2015_16/measures/documents/sb439_02_0000.pdf. The bill died in the House Judiciary Committee, however. See S.B. 439, 2016 Leg. Sess. (Kan. 2016), http://www.kslegislature.org/li 2016/b2015 16/measures/sb439/. For further discussion of S.B. 439, see infra notes 53-57 and accompanying text. Another example, from the 2014 session, was S.B. 364. That bill would have stripped the Supreme Court of its power to allocate annual budgets for each of the thirty-one judicial districts, instead granting each judicial district the power to allocate its own budget. S.B. 364, 2014 Leg. Sess. (Kan. 2014) (as amended by Senate Committee), http://www.kslegislature.org/li_2014/b2013_14/measures/documents/sb364_01_0000.pdf. This bill, if passed, would probably be unconstitutional. See KAN. CONST. art. III, § 1 ("The supreme court shall have general administrative authority over all courts in this state."). The bill died when it was stricken from the legislative calendar. See S.B. 364, 2015 Leg. Sess. (Kan. 2014), http://www.kslegislature.org/li_2014/b2013_14/measures/sb364/. Although there were others, these examples should be sufficient to illustrate the general point.

29. See Daniel Salazar, Kansas Judicial Selection Measure Falls Short of Votes, WichitA EAGLE (Feb. 3, 2016), http://www.kansas.com/news/politics-government/article58192398.html. There are principled arguments to support this change and many advocates may have principled reasons for supporting it. See infra notes 63-80 and accompanying text (discussing debate over judicial selection methods). Nonetheless, it is reasonable to attribute political motives to politicians, especially when — given the context — the result of the change would so clearly further their political interests by giving them control over the judiciary.

30. Under the previous model, often referred to as merit selection, the governor would make an appointment from a list of three candidates selected by a nominating commission. See Caplan, supra note 1 . The new statute followed the federal model, providing for the governor to nominate his or her preferred candidate, subject to Senate confirmation. See KAN. STAT. ANN. § 20-3020 (Supp. 2016). 
to garner the necessary supermajority to present an amendment to the voters. ${ }^{31}$ In 2014 , the legislature adopted two other statutes targeting the judiciary. The more highprofile statute stripped the Kansas Supreme Court's authority to appoint the chief judge of each district, providing instead for the election of the chief judge by the judges of the district. $^{32}$ Perhaps in anticipation of a challenge to this provision, which was included in the appropriations bill for the judiciary, the legislature included a non-severability clause (and added a similar provision to the following year's appropriations bill), specifying that if any provision of the law were to be invalidated, the entire law was invalid. ${ }^{33}$ This maneuver was widely perceived as an effort to blackmail the courts by threatening to cut off funding if the courts invalidated the law. ${ }^{34}$ Another, less well known provision adopted at roughly the same time set a deadline for deciding cases on appeal. ${ }^{35}$

- Controversial Judicial Decisions or Other Actions: For its part, the judiciary did not hesitate to render decisions or take other actions likely to provoke strong reactions from

31. See Salazar, supra note 29. The use of merit selection for Supreme Court justices is mandated by Article 3, $\S 5$ of the Kansas Constitution, which was adopted in 1958 in response to the so-called "triple play" of 1956-57, through which outgoing Governor Fred Hall became chief justice of the Kansas Supreme Court. See Kan. Historical Soc'y, Political "Triple Play" Resignations and Oaths of Office, KAN. MEMORY, http://www.kansasmemory.org/item/228731 (last visited Apr. 1, 2017). Hall had lost in a primary to Warren Shaw, who lost the general election to George Docking. The triple play worked as follows. Id. First, Governor Hall's longtime friend, Chief Justice Joseph Smith, resigned on December 31, 1956, shortly before the end of Hall's term. Id. Second, Hall resigned as governor on January 3, 1957, allowing his lieutenant governor, John McCuish, to assume office. Id. Third, that same day in his sole official act, Governor McCuish appointed Hall to be chief justice of the Kansas Supreme Court. Id.

32. See Kan. StAT. AnN. § 20-329 (Supp. 2016), invalidated by Solomon v. State, 364 P.3d 536 (Kan. 2015).

33. H.B. 2338, 2014 Reg. Sess. § 43 (Kan. 2014), http://www.kslegislature.org/li_2014/b2013_14/measures/documents/hb2338_enrolled.pdf (severability clause in original appropriations bill). See also H.B. 2005, 2015 Reg. Sess. § 29 (Kan. 2015), http://www.kslegislature.org/li_2016/b2015_16/measures/documents/hb2005_enrolled.pdf (specifying that provisions of 2015 appropriations bill were not severable from provisions of 2014 appropriations bill).

34. It was this measure, in particular, that attracted the attention of the national media, and gave me the opportunity, as a local professor of constitutional law, to be quoted by the New York Times and the Wall Street Journal. See supra note 1. I remember disappointing one reporter by my refusal to use the term "blackmail" in characterizing the law, although I did express my concern that this sort of linkage threatens judicial independence. See infra notes 95-106 and accompanying text (discussing implications of the non-severability clause for judicial independence).

35. See KAn. StAT. AnN. § 20-3301 (Supp. 2016). 
conservative politicians. Thus, when the failure to provide promised funding for schools precipitated a new round of school finance litigation, the Kansas Supreme Court emphatically rejected the state's argument that such issues were non-justiciable political questions. ${ }^{36}$ Nonetheless, the Court did delay the day of reckoning on the adequacy of funding by remanding on the issue. ${ }^{37}$ Likewise, the Kansas Supreme Court was not intimidated by statutes targeting the courts; it invalidated both the statute removing its power to appoint chief judges and the statute imposing deadlines for issuing appellate decisions. ${ }^{38}$ More broadly, the courts did not shy away from other controversial decisions, including decisions setting aside the death penalty in the infamous Carr brothers case $^{39}$ and an en banc decision by the court of appeals in which the judges were evenly split on the recognition of the right to abortion under the Kansas Constitution. ${ }^{40}$ On the other hand, Kansas courts were able, for the most part, to stay out of the fray with respect to samesex marriage and the constitutionality of the Kansas Marriage Amendment, leaving such issues to the federal courts. $^{41}$

36. Gannon v. State (Gannon I), 319 P.3d 1196, 1216-23, 1251 (Kan. 2014).

37. Id. at $1237-38$ (remanding adequacy question to lower court for reconsideration under newly announced standard for determining adequacy). After remand, the trial court reaffirmed its finding that funding was constitutionally inadequate. Gannon v. State, No. 2010CV1569, SHAwNEE Ст. (Kan. Dist. Ct. Dec. 30, 2014), http://www.shawneecourt.org/DocumentCenter/View/527. The Kansas Supreme Court recently affirmed that finding. Gannon v. State (Gannon IV), No. 113,267, 2017 WL 833551 (Kan. Mar. 2, 2017). For further discussion of the implications of Gannon IV, see infra notes 116-129 and accompanying text.

38. See Solomon v. State, 364 P.3d 536, 549-50 (Kan. 2015) (holding that statute providing for local judges in each district to elect their chief judge improperly infringed on the Kansas Supreme Court's responsibility for the administration of the courts); see also State v. Buser, 302 Kan. 1, 12-14, 2015 WL 4646663, at*9-10 (2015) (holding that remedies for delay in rendering appellate decisions improperly encroached on judicial power).

39. State v. Carr, 331 P.3d 544 (Kan 2014); State v. Carr, 329 P.3d 1195 (Kan. 2014). The United States Supreme Court later reversed the Kansas Supreme Court in these cases, as well as another decision setting aside a death penalty sentence on similar grounds. Kansas v. Carr, $136 \mathrm{~S}$. Ct. 633, 643-44, 646 (2016).

40. Hodes \& Nauser, MDs, P.A. v. Schmidt, 368 P.3d 667, 678-79 (Kan. Ct. App. 2016) (en banc), review granted (Apr. 11, 2016).

41. Prior to the United States Supreme Court's definitive resolution of this issue in Obergefell v. Hodges, 135 S. Ct. 2584 (2015), one chief district judge issued an order directing personnel in the district to grant licenses to same-sex couples, concluding that lower court decisions on the issue were sufficiently authoritative to require this step. See Tony Rizzo \& Glenn E. Rice, Same-Sex Couples Now Can Legally Marry in Johnson County, KAn. CITY STAR (Oct. 8, 2014), http://www.kansascity.com/news/politics-government/article2625194.html. But the Attorney 
As this overview of events suggests, in the run up to the November 2016 elections, tensions between the political branches and the judiciary were running high. These tensions had both institutional and ideological dimensions. Institutionally, there is a natural friction between the judiciary and the political branches, insofar as the judiciary's institutional power and responsibility includes the invalidation of unconstitutional and unlawful actions by the political branches. Such decisions never sit well with the legislature and Governor, who often perceive them as overreaching by the judiciary. This sort of institutional friction has been especially acute with respect to school finance. But when this natural institutional friction was exacerbated by sharp ideological differences and the courts loomed as the only substantial obstacle to the implementation of a conservative political agenda, the conflict became acute. It is hardly surprising, then, that conservative forces would target four "liberal" Kansas Supreme Court justices (Beier, Biles, Luckert, and Nuss) whose retention was on the ballot. ${ }^{42}$

\section{LETTER THREE: GOOD JUDGE HUNTING}

Dear Readers:

When we talk about the independence of the judiciary, we mean first and foremost that the judiciary is not part of or answerable to the legislative or executive branches (or any other superior authority). ${ }^{43}$ This

General filed a mandamus action and the Kansas Supreme Court issued a stay. See State ex rel. Schmidt v. Moriarty, No. 112,590 (Nov. 18, 2014), http:/www.kansas.com/news/politicsgovernment/article4013159.ece/binary/Kansas\%20Supreme\%20Court\%20order.pdf.

42. I use the term "liberal" advisedly here. Like the term "conservative," the term "liberal" means different things to different people. Likewise, both are relative terms. Thus, I would not characterize the Kansas Supreme Court as especially "liberal," at least not on all issues and not by comparison to the highest courts of other states. Nonetheless, the Kansas Supreme Court is clearly liberal by comparison to the Governor or the conservative wing of the legislature. See supra notes 18-41 and accompanying text (discussing conflicts between the political branches and the Kansas courts).

43. See Plaut v. Spendthrift Farm, Inc., 514 U.S. 211, 219-25 (1995) (discussing the historical background of judicial independence in the United States). Note that this sort of independence may be more a matter of practical control than formal status. Thus, for example, the French Conseil d'Etat is part of the executive branch. See C.J. HAMson, ExECUTIVE Discretion And JUdiciaL CONTROL: AN ASPECT OF THE FRENCH CONSEIL D'ETAT 45-46 (1954). The situation is even more complicated in the United Kingdom, where the ordinary courts originated as an arm of the crown and continue to be administered by the Ministry of Justice, which are part of her Majesty's Government. See The Justice System and the Constitution, CTS. \& TRIBUNALS JudiCIARY, https:/www.judiciary.gov.uk/about-the-judiciary/the-judiciary-the-government-and-the-

constitution/jud-acc-ind/justice-sys-and-constitution/ (last visited Apr. 1, 2017). Until recently, the House of Lords, a component of Parliament, also served in a judicial capacity as the final court of appeals. Glenn Dymond, Library Note: The Appellate Jurisdiction of the House of Lords 11 (Nov. 20, 2009), http://www.parliament.uk/documents/lords-library/lln2009-010appellate.pdf. 
sort of functional independence is necessary both as a matter of fundamental fairness in individual cases and to ensure that the courts can serve their role in holding government actors accountable to the rule of law. ${ }^{44}$ In individual cases, a lack of judicial independence creates the very real risk that external pressures will compromise judicial impartiality to a degree that is incompatible with due process of law. ${ }^{45}$ Equally important, judges who are controlled by the legislative or executive branches cannot be expected to zealously enforce constitutional and other legal limits on government action. ${ }^{46}$

Accordingly, both federal and state courts in the United States are structurally independent from the legislative and executive branches, which have no authority to oversee judicial decisions, either by directing outcomes or by reviewing and altering a decision. ${ }^{47}$ Structural

Notwithstanding the lack of formal structural independence of these judicial bodies in France and the United Kingdom, they enjoy sufficient functional independence to serve their roles in preserving the rule of law. See generally Michel Rosenfeld, The Rule of Law and the Legitimacy of Constitutional Democracy, 74 S. CAL. L. REV. 1307 (2001) (discussing German, French, and Anglo-American rule of law traditions).

44. In so doing, the courts also hold the people accountable to the dictates of the constitution as well. Thus, for example, in cases like Brown v. Board of Education, 347 U.S. 483 (1954) (requiring desegregation of the schools), and more recently Obergefell v. Hodges, $135 \mathrm{~S}$. Ct. 2584 (2015) (requiring states to allow same-sex couples to marry), the Court's decisions were directed at the states' political institutions, but those changes implicated widely held and deeply felt social attitudes. In such cases, respect for the rule of law is especially important.

45. See, e.g., Caperton v. A.T. Massey Coal Co., 556 U.S. 868, 873-76, $884-87$ (2009) (holding that failure of a West Virginia Supreme Court justice to recuse himself from case in which one of the litigants had contributed millions of dollars in campaign spending on his behalf violated due process).

46. The recent litigation concerning President Trump's executive orders imposing a travel ban on certain immigrants illustrates this point. See Washington v. Trump, 847 F.3d 1151, 1168-69 (9th Cir. Feb. 9, 2017) (refusing to stay lower court order enjoining of initial executive order); Hawai'i v. Trump, CV No. 17-00050 DKW-KSC, 2017 WL 1167383, at *9 (D. Haw. 2017) (enjoining revised executive order); Int'l Refugee Assistance Project v. Trump, CV No. TDC-17-0361, 2017 WL 1018235, at*18 (D. Md. 2017). See also Ali v. Trump, No. C17-0135JLR,

2017 WL 1057645, at*5-6 (W.D. Wash. 2017) (staying action on motion for temporary restraining order against revised executive order so long as a nationwide order or injunction was in place); Washington v. Trump, No. C17-0141JLR, 2017 WL 1050354, at *5-6 (W.D. Wash. 2017) (same). Contra Sarsour v. Trump, No. 1:17cv00120, 2017 WL 1113305, at *15-16 (E.D. Va. 2017) (refusing to issue temporary restraining order against revised executive order). This sort of decision would be far less likely if courts had to fear retaliation from the President and Congress. To be sure, those who favor the executive order might argue that the court was wrong and is guilty of overreaching, but those same people would likely applaud the federal court order enjoining President Obama's executive action deferring removal for certain classes of undocumented aliens. See Texas v. United States, 809 F.3d 134, 186-88 (5th Cir. 2015), aff'd by an evenly divided court, $136 \mathrm{~S}$. Ct. 2271 (2016). In this sense, judicial independence is neither inherently conservative nor inherently liberal, but rather depends on the juxtaposition of the court and the political branches.

47. To be sure, the political branches can reverse or alter the law made by judicial decisions; that is, they can overturn common law or statutory decisions by passing new laws and overturn constitutional decisions by amending the constitution. These steps, however, do not threaten the 
independence standing alone, however, is not sufficient to secure judicial independence; judges also need protection from improper forms of political retaliation. Recognizing that the fear of punishment might affect judicial decisions, the framers of the United States Constitution insulated the judiciary from such threats by providing for life tenure and prohibiting any reduction in their salaries. ${ }^{48}$

The Kansas Constitution provides similar protections, but these protections are less absolute than in the federal system. ${ }^{49}$ First, like the federal Constitution, the Kansas Constitution prohibits the reduction of judicial salaries, but this prohibition is subject to an exception that permits such a reduction by means of a general law applicable to all state officials. ${ }^{50}$ Second, the Kansas Constitution provides for removal by impeachment, but it also permits the forced retirement of judges (after a hearing) if they become so incapacitated that they can no longer adequately perform their duties. ${ }^{51}$ Although neither of these qualifications is a significant departure from the federal model, the Kansas Constitution also requires Supreme Court justices to stand for retention elections, which has more serious implications for judicial independence. ${ }^{52}$

independence of the judiciary because they do not punish the judges who make the decision or alter the outcome of particular cases. See Plaut, 514 U.S. at 227-30 (holding that a statute reversing the Supreme Court's interpretation of the statute of limitations for certain civil actions applied in pending cases but could not reopen final decisions dismissing cases). In contrast, for example, the leaders of executive agencies can ordinarily tell their subordinates what to do and overrule actions with which they disagree. Of course, this power may require the threat of removal from office or of other sanctions to be effective.

48. U.S. CONST. art. III, $\S 1$ ("The Judges, both of the supreme and inferior Courts, shall hold their Offices during good Behaviour, and shall, at stated Times, receive for their Services, a Compensation, which shall not be diminished during their Continuance in Office.”).

49. Somewhat different rules and provisions apply to supreme court justices, appellate judges, and trial judges. Compare KAN. CONST. art. 3, 5 ("Selection of justices of the supreme court"), KAN. CONST. art. 3, § 6 ("District Courts"), and KAN. STAT. ANN. § 20-2901 (2007) ("Proposition of method of selection of judges of district court; submission of proposition on filing of petition or in newly established district"), with KAN. STAT. ANN. § 20-3020 (Supp. 2016) (“Judges; appointment by governor; consent of senate; time limitations; commencement of judges' duties; qualifications"). I will focus here primarily on the Kansas Supreme Court, because it is the highest court in the state and its independence is therefore the most critical.

50. KAN. CONST. art. $3, \S 13$ ("The justices of the supreme court and judges of the district courts shall receive for their services such compensation as may be provided by law, which shall not be diminished during their terms of office, unless by general law applicable to all salaried officers of the state.").

51. KAN. CONST. art. $3, \S 15$ (providing for removal by impeachment and for retirement of judges based on incapacity); see also KAN. CONST. art. 2, §§ 27-28 (specifying procedures and grounds for impeachment and removal). In addition, the Kansas Supreme Court can discipline, suspend, or remove lower court judges for good cause. KAN. CONST. art. $3, \S 15$.

52. See KAN. CONST. art. 3, $\S 5(\mathrm{c})$ (providing that Supreme Court justices must stand for retention in the first regular election following their appointment and every six years after that); 
Given their unhappiness with the composition of the Supreme Court, it is not surprising that some conservatives would seek to remove some justices from the court. One approach worth noting is S.B. 439, a bill considered in the 2016 legislative session that would have defined the grounds for impeachment of judges broadly. ${ }^{53}$ Among other things, the bill would have allowed the removal of justices for "failure to perform adequately the duties of office," "attempting to subvert fundamental laws and introduce arbitrary power," "attempting to usurp the power of the legislative or executive branch," "exhibiting discourteous conduct" in their official capacity, or "exhibiting wanton or reckless judicial conduct., 54

In my view, S.B. 439 would be a severe threat to judicial independence and almost certainly would be unconstitutional. The Kansas Constitution (like its federal counterpart) permits impeachment for and removal upon conviction of "treason, bribery, or other high crimes and misdemeanors." 55 There is no plausible interpretation of this phrase that would include some of the grounds listed in the bill, such as "exhibiting discourteous conduct." 56 That such a bill would pass the Senate, even if it died in House Committee, is a testament to the level of legislative frustration with the courts. ${ }^{57}$

Of course, the more direct strategy for reshaping the Supreme Court was the effort to unseat four justices in the 2016 elections. This effort, which is clearly permissible under the Kansas Constitution, highlights one critical concern with retention elections - they may compromise judicial independence. To be sure, retention elections are less of a threat to judicial independence than giving the political branches power to remove or punish judges would be, and uncontested retention elections are less of a threat to judicial independence than contested partisan elections. $^{58}$

KAN. StAT. ANN. § 20-3006 (Supp. 2016) (providing that court of appeals judges must stand for retention in the first regular election following their appointment and every four years after that). This sort of retention election is generally associated with the use of nominating commissions to select judges. See generally G. Alan Tarr, Do Retention Elections Work?, 74 Mo. L. REv. 605 (2009) (arguing, inter alia, that nonpartisan retention elections have not eliminated politicization of judicial elections). For further discussion of nominating commissions, see infra notes $63-80$ and accompanying text.

53. See supra note 28 .

54. S.B. 439, 2016 Leg. Sess. $§ 1$ (Kan. 2016) (as amended by the Senate Committee of the Whole), http://www.kslegislature.org/li_2016/b2015_16/measures/documents/sb439_02_0000.pdf.

55. KAN. CONST. art. $2, \S 28$.

56. S.B. 439 , supra note $54, \S 1(\mathrm{~h})$.

57. See supra note 28 and accompanying text (discussing proposals targeting the courts).

58. Partisan elections are a problem because judges must campaign and because those 
Indeed, although retention elections rarely result in the ouster of sitting judges, when they do it is usually in reaction to controversial decisions. ${ }^{59}$ Given this reality, we cannot discount the very real possibility that the prospect of adverse public reactions to unpopular decisions might influence a judge with a pending retention election. Indeed, it is precisely when public sentiment runs high and may lead to retaliation by voters in a retention election that the need for judicial independence is at its greatest.

For these reasons, I was relieved that voters voted to retain all of the Kansas judges who were on the ballot in the November 2016 elections, including not only the four liberal justices targeted by conservative groups because of their decisions, but also Justice Stegall, who was not. ${ }^{60}$ I want to emphasize that I take this position not because I oppose the conservative agenda, but rather because I want the courts to remain independent. I would take the same position in a "blue" state in which liberal or progressive groups targeted conservative justices because of unpopular decisions protecting gun rights, property owners, or religious exemptions for individuals who oppose same-sex marriage.

The results of the elections provide some assurance that the state's Supreme Court justices do not risk losing their positions based on unpopular decisions. This is not to say that the threat of being targeted for non-retention is trivial. Such a campaign forces judges (or their surrogates) to defend themselves at potentially great cost in terms of time, effort, and resources, and it may ultimately reduce the margin of safety. While sitting judges typically receive an excess of $70 \%$ of the vote in a retention election, ${ }^{61}$ the margin of retention for the targeted justices was much narrower, as each received roughly $55 \%$ to $56 \%$ of the vote in favor of retention. ${ }^{62}$ Nonetheless, given the totality of the

campaigns cost money. Seeking and accepting such contributions creates the appearance, if not the reality, that judges will be beholden to their contributors.

59. See, e.g., A. G. Sulzberger, Ouster of Iowa Judges Sends Signal to Bench, N.Y. TIMES (Nov. 3, 2010), http:/www.nytimes.com/2010/11/04/us/politics/04judges.html (discussing successful campaign in retention election to oust Iowa Supreme Court justices who voted in favor of recognizing a right to same-sex marriage).

60. 2016 General Election Results, supra note 3, at 12; Christina A. Cassidy, Control of State Courts Becomes a Top Political Battleground, AssociATEd Press (Apr. 3, 2016), http://bigstory.ap.org/article/0b62b60670b148ab9611a5a8b58cb48f/control-state-courts-becomestop-political-battleground ("Groups supportive of Republican Gov. Sam Brownback and the GOPcontrolled Legislature will be looking to oust four of the five justices up for retention elections in November, enabling Brownback to select their replacements to the seven-member court.").

61. Tarr, supra note 52, at 627 ("Retention races are rarely close: the mean yearly average positive vote has ranged from a low of sixty-nine percent in 1990 to a high of eighty-five percent in 1964 and has not fallen below seventy-five percent over the last decade.").

62. 2016 General Election Results, supra note 3, at 12. Justice Stegall, who is widely 
circumstances, if non-retention efforts failed in this election cycle, it seems unlikely that justices in Kansas need fear non-retention in any but the most extreme case.

In the absence of direct oversight authority or the ability to remove or otherwise punish judges for unpopular decisions, the battle for control over the judiciary typically focuses on judicial appointments. Although judicial appointments certainly influence the direction of the courts, they do not represent the same challenge to judicial independence. Ideology, political affiliations, and past judicial actions may give some indication of a prospective judge's likely jurisprudence, but there are many examples of appointments that did not pan out as expected. Critically, moreover, once judges are appointed the bench, there is little or nothing that can be done to "discipline" them if they do not decide cases as expected. Nonetheless, judicial appointments do have important implications for judicial independence and the rule of law.

In Kansas, the means of appointing judges has been the focus of considerable debate. The federal model requires nomination by the President that is subject to Senate confirmation, ${ }^{63}$ and some states follow this model. ${ }^{64}$ Most states, however, use either elections or nominating commissions to select judges. ${ }^{65}$ Nominating commissions, which typically include a special role for members of the bar, forward a list of (typically three) nominees, from which the Governor chooses one. This method of selection-referred to as "merit selection" or the "Missouri plan"-usually incorporates uncontested retention elections to provide a measure of democratic accountability. ${ }^{66}$ Its supporters argue that it

regarded as conservative and was not targeted, see supra note 2, received the more typical retention margin of about 71 percent of the vote. 2016 General Election Results, supra note 3, at 12. This differential suggests that at least 15 percent $(71-56 \%)$ of voters responded to the political campaign to oust those four justices. See id. Without more data, it is impossible to know whether the remaining votes represent voters who voted to oust $(29-30 \%)$ or retain $(55-56 \%)$ all the justices, or whether some ideologically based votes for and against liberal and conservative justices cancelled each other out.

63. Frequently Asked Questions, U.S. https://www.supremecourt.gov/faq.aspx\#faqgi1 (last visited Apr. 1, 2017).

64. Examples include Maine and New Jersey. See ME. Const. art. V, pt. 1, § 8; N.J. Const. art. VI, § VI, I 1. There are, however, many variations, and some states use both nominating commissions and legislative approval for the governor's appointments, while others require approval by some other designated body. See generally Stephen J. Ware, Selection to the Kansas Supreme Court, 17 KAN. J.L. \& PUB. POL'Y 386, 388-91 (2008).

65. See generally Rachel Paine Caufield, The Evolving Patchwork of Judicial Selection in the United States, 53 ADVOCATE 85, 90-94 (2010) (providing a breakdown of appointment methods in the states); Ware, supra note 64, at 386-91 (same).

66. Stephen J. Ware, The Missouri Plan in National Perspective, 74 Mo. L. REV. 751, 758-64 (2009). 
results in the selection of judges based on merit and that it avoids the risks associated with partisan judicial elections.

Until recently, Kansas used nominating commissions to select Supreme Court justices, court of appeals judges, and some lower court judges, although individual judicial districts could opt for judicial elections for district court judges instead. With increasing tensions between conservatives and the court, changing the method of selecting judges became an important objective for conservatives and Republicans in the state. As noted above, the legislature adopted a statute shifting to the federal model for appointment of court of appeals judges, but advocates fell short of the needed votes for a constitutional amendment to change the means of selecting Kansas Supreme Court justices. ${ }^{67}$ Insofar as the Kansas Supreme Court is the court of last resort and has the final say on matters of Kansas law, the failure to change the means of selecting Supreme Court justices is probably more significant than the change in the means of selecting court of appeals judges.

The essential argument against the use of nominating commissions is that they are elitist and tend to skew judicial policy to the left (because they are most common in conservative states and the bar as a whole is more liberal than the general population). ${ }^{68}$ Thus, the argument continues, because judges inevitably make policy when they develop common law principles, interpret statutes, and apply constitutional provisions, the selection process should represent the people, at least indirectly, and should not give disproportionate power to the bar. ${ }^{69} \mathrm{My}$ friend and colleague Steve Ware has been a leading advocate of this position. ${ }^{70}$ While we have had many discussions of the subject and I

67. See supra note 29-31 and accompanying text.

68. See, e.g., James Bopp, Jr., The Perils of Merit Selection, 46 IND. L. REV. 87, 99 (2013) (“A disconnect between the ideological preferences of the People and the commission is thus inevitable given that lawyers, as a group, are more liberal than the general public ...."); Brian T. Fitzpatrick, The Politics of Merit Selection, 74 Mo. L. REV. 675, 690 (2009) ("[M]any people believe that lawyers are, on average, more liberal than are the members of the general public.").

69. See, e.g., Nelson Lund, May Lawyers Be Given the Power to Elect Those Who Choose Our Judges? "Merit Selection" and Constitutional Law, 34 HARV. J.L. \& PUB. POL'Y 1043, 1046-47 (2011) (arguing this approach violates equal protection).

70. See generally Stephen J. Ware, Originalism, Balanced Legal Realism and Judicial Selection: A Case Study, 22 KAN. J.L. \& PUB. POL'Y 165 (2013); Stephen J. Ware, The Missouri Plan in National Perspective, 74 Mo. L. REv. 751 (2009); Stephen J. Ware, The Bar's Extraordinarily Powerful Role in Selecting the Kansas Supreme Court, 18 KAN. J.L. \& PUB. POL'Y 392 (2009); Stephen J. Ware, Selection to the Kansas Supreme Court, 17 Kan. J.L. \& PUB. PoL'Y 386 (2008). See also Stephen J. Ware, Judicial Elections, Judicial Impartiality and Legitimate Judicial Lawmaking: Williams-Yulee v. The Florida Bar, 68 VAND. L. REV. EN BANC 59 (2015) (discussing implications of campaign finance in judicial elections for judicial decisions). 
recognize the principled arguments in support of the federal model, this is a topic on which we disagree. ${ }^{71}$

I think the argument for a representative judicial selection process rests on a false premise. Unlike legislators, elected officials in the executive branch, or even political appointments, judges do not represent people or constituencies. ${ }^{72}$ They represent the law. The proper measure of a means of judicial appointment is the extent to which such a method is likely to result in the appointment of judges who seek to properly interpret and apply the law, not the extent to which the inevitable policy choices implicit in such decisions align with the policy preferences of voters in the state. In my view, the fact that judges must make policy is a reason to minimize the extent to which their ideology drives their decision making, rather than an argument in favor of placing their appointment in the hands of partisan politicians.

To develop this point, we may consider the factors that motivate judicial decisions. ${ }^{73}$ Judges do not stand to gain directly from their decisions, and the usual financial and career incentives that motivate people in the work environment do not apply. Judges do not get fired, merit raises and bonuses are off the table, and promotion to a higher court is rare. Under these conditions, judges are motivated or incentivized by other factors, including craft norms and ideological consumption. $^{74}$

71. I note here that adopting the federal model (or using nominating commissions) may be defended on the basis of principle or as a matter of political expediency. For the principled advocate, it is immaterial whether changing the means of selection would result in judges whose decisions are more conservative or liberal. Supporters who advocate for such a means of selection because it is likely to produce a more conservative or liberal bench (and would not do so if the result were different) do so as a matter of political expediency. In practice, of course, it may be hard to tell the difference, and some readers will be skeptical of my own effort to analyze these matters independently of their political implications.

72. For this reason, the selection of judges is different from the selection of political officials. In the latter case, application of the one-person, one-vote principle might be appropriate. See Richard E. Levy, Written Testimony of Richard E. Levy Before the House Agriculture Committee, State of Kansas, 42 U. KAN. L. REV. 265, $282 \mathrm{n} .118$ (1994) (suggesting that the use of a nominating commission with disproportionate representation of agricultural interests to nominate candidates for the position of Secretary of Agriculture might violate the one-person, one-vote principle). Several federal courts of appeals have therefore rejected constitutional challenges to the use of nominating commissions, including the Kansas Supreme Court Nominating Commission. See Dool v. Burke, 497 Fed. App'x 782, 784 (10th Cir. 2012) (unpublished opinion); Carlson v. Wiggins, 675 F.3d 1134, 1140-42 (8th Cir. 2012); Kirk v. Carpeneti, 623 F.3d 889, 896-900 (9th Cir. 2010).

73. This discussion draws upon a model of judicial behavior that I developed with Sid Shapiro a number of years ago. See Sidney A. Shapiro \& Richard E. Levy, Judicial Incentives and Indeterminacy in Substantive Review of Administrative Decisions, 44 DUKE L.J. 1051, 1052-79 (1995) (articulating model and considering its implications for the scope of review of agency decisions).

74. A third incentive might be minimizing the time and effort involved in judging or 
- Craft norms refer to norms of the legal profession and the judiciary that demand reasoned explanations for decisions based on the interpretation and application of law to the facts of a case. ${ }^{75}$ Judges have incentives to pursue craft norms both for their own sake and because a reputation for craft enhances a judge's prestige and influence. ${ }^{76}$

- Ideological consumption refers to the utility derived from influencing public events in accordance with one's worldview, which may be valuable because it furthers (at least indirectly) a judge's self-interest, ${ }^{77}$ and because of principles of individual or social justice that transcend any identifiable self-interest.

In practice, we may expect that all judges will value both craft norms and ideological consumption, and that the relative weight of these two considerations is not material when the results indicated by craft and ideology are the same. The critical question is which value judges will prioritize when the two are in conflict.

In my view, judges who value craft norms over ideological consumption better serve judicial independence and the rule of law because they are more likely, in any given case, to seek objectively to determine what the law is and apply it objectively, even if (as human beings) they do so imperfectly. By contrast, ideologically motivated judges are more likely to read the law to further their ideological preferences, reject precedents with which they disagree, and thereby unsettle the rule of law. More broadly, the more judges are perceived as political actors driven by ideology, the less likely they are to have the necessary legitimacy in the minds of the general public to represent the rule of law.

From this perspective, how we select judges matters. The more political and ideological the method of selection, the more likely it is to select judges who are ideologically oriented. Thus, from the perspective of judicial independence and the rule of law, the worst means of

\footnotetext{
promoting leisure, in the sense that judges might make decisions that are the easiest to write or that reduce their caseloads in the future. This incentive is not central to our model, however, and will be discounted.

75. Shapiro \& Levy, supra note 73 , at 1053.

76. Id. at $1055-57$.

77. Eric A. Posner \& Adrian Vermeule, Inside or Outside the System?, 80 U. CHI. L. REV. 1743, 1777-78 (2013). For example, a decision benefiting property owners would, at least indirectly, benefit a judge who is a property owner. To the extent that our ideologies often align with our self-interest, this sort of benefit may be common, even if judges do not consciously pursue it.
} 
selecting judges is through elections - even if, once elected, they do not have to worry about removal or reelection. A craft orientation is not conducive to running for judicial election as a Democrat or Republican, or even as a nonpartisan candidate whose positions must appeal to voters. For similar reasons, moving to the federal model would likely increase the ideological orientation of the state's Supreme Court judges, as reflected in the experience we have had in selecting federal judges.

The federal nomination process has been all too political and ideological. As the battle over replacing Justice Scalia on the United States Supreme Court reflects, the President and Senators care deeply about the ideology of these appointments. To be sure, both Republicans and Democrats are acutely aware of the ideological preferences of judicial nominees, and it has been increasingly difficult to appoint judges with extreme ideological views. In a strongly red state or strongly blue state, however, there might be nothing to prevent the appointment of ideologically extreme or politically partisan judges, thereby undermining the ability or willingness of the courts to enforce the rule of law as against their political and ideological allies. ${ }^{78}$

More broadly, research into the outcomes of federal judicial decisions shows a strong correlation between the party appointing a federal judge and the judge's votes in ideologically charged decisions. ${ }^{79}$ To me, this sort of correlation raises the concern that judicial decisions are the product of ideological preferences rather than the product of judicial craft. To be sure, this sort of decision making is not necessarily a matter of a conscious choice to produce a given result at any cost. Nonetheless, the more a judge cares about his or her ideology, the more likely it is that his or her ideology will influence the outcomes of decisions. Conversely, the more a judge cares about craft, the more likely it is that craft norms will guide the decision.

Because I believe that the judicial method, as reflected in craft norms, is essential to judicial independence and the rule of law, I want judges who value craft. It is the judicial method that legitimizes the

78. In such a state, moreover, control of the Senate does not change hands, and the federal model is unlikely to result in ideological diversity or balance on the courts.

79. See, e.g., Frank B. Cross \& Emerson H. Tiller, Judicial Partisanship and Obedience to Legal Doctrine: Whistleblowing on the Federal Courts of Appeals, 107 YALE L.J. 2155 (1998) (providing statistical analysis that documents correlations between the political party of a judge's appointing President and outcomes in politically charged cases, but noting that effect diminishes when a panel includes a judge appointed by a President from the other party); Cass R. Sunstein et al., Ideological Voting on Federal Courts of Appeals: A Preliminary Investigation, 90 VA. L. REV. 301 (2004) (providing statistical analysis that documents correlations between the political party of a judge's appointing President and outcomes in politically charged cases). 
judiciary as the neutral arbiter of legal disputes with the ultimate power to say what the law is, not its accountability to the electorate or the congruence of its ideology with the ideological preferences of the people of a state. From the rule-of-law perspective then, we want judges who are committed to judicial craft norms, as opposed to a particular ideology. On balance, I believe that using a nominating commission is more likely than elections or the federal model to produce that result. ${ }^{80}$

\section{LETTER FOUR: THE UMPIRES STRIKE BACK}

Dear Readers:

Although the judiciary has an independent constitutional status that prevents direct legislative or executive control, it is necessarily dependent on the legislature and the executive branch for the effectiveness of its operations. The courts could not function without legislative action to create the judicial system, to provide for civil and criminal actions and procedures, and to appropriate funds to support the operation of the courts. Likewise, the courts are dependent upon the executive branch to comply with, implement, and enforce their decisions. The question becomes how these respective roles affect the balance of power when the political branches disagree with judicial decisions.

One set of issues concern the extent to which the legislature can use its general authority to provide for the creation, jurisdiction, and operation of the courts as a means for limiting judicial power or punishing the courts for decisions with which it disagrees. ${ }^{81}$ Three examples noted above illustrate this issue: special provisions for school finance litigation, provisions divesting the Kansas Supreme Court of power to appoint chief district judges, and time limits on appellate

80. To be sure, a nominating commission is only likely to produce craft-based nominations if the body itself is not ideological and chooses judges based on factors related to judicial craft. In this sense, how a nominating commission is comprised-who makes the appointments and what constituencies those appointments draw from is a major factor. To the extent there are concerns about the ideological orientation of the Kansas Supreme Court Nominating Commission, that concern might warrant consideration of changing its composition or the means through which members are selected. Any detailed examination of that question is beyond the scope of this essay.

81. At the federal level, for example, there is a longstanding but unresolved debate over the extent to which Congress may divest the federal courts of jurisdiction over cases and controversies. Compare Henry M. Hart, Jr., The Power of Congress to Limit the Jurisdiction of Federal Courts: An Exercise in Dialectic, 66 HARV. L. REV. 1362 (1953) (arguing that Congress may not limit jurisdiction so as to destroy the essential function of the courts), with Herbert Wechsler, The Courts and the Constitution, 65 COLUM. L. REV. 1001 (1965) (arguing that Congress has the authority to decide the extent to which federal courts would be used). See generally ERWIN CHEMERINSKY, CONSTITUTIONAL LAW: PRINCIPLES AND POLICIES 155-86 (5th ed. 2015) (discussing various aspects of the debate). 
decisions. Each of these measures limits the courts and some of them seem to be motivated at least in part as retaliation against the courts for their decisions. None of these measures, however, has deterred the Kansas courts, which have avoided or invalidated each of them.

First, the Kansas Legislature enacted special statutory provisions concerning school finance litigation in the wake of Montoy. The reforms provided for the formation of a special three-judge panel to hear litigation challenging the suitability of educational funding. ${ }^{82}$ This provision is worth discussing briefly, even though it does not raise any serious constitutional issues. Providing for the formation of a threejudge panel does not limit the jurisdiction or powers of the courts and in that sense does not encroach upon judicial power. ${ }^{83}$ Conversely, there are sound reasons, in keeping with the appropriate legislative regulation of the judicial system, for assigning cases this important to a three-judge panel rather than to a single judge. ${ }^{84}$ Thus, a three-judge panel appointed under this statute tried the Gannon case without any objection. ${ }^{85}$

Another part of this reform, however, prohibits Kansas courts from closing schools or enjoining funding for schools as a remedy for a constitutional violation. ${ }^{86}$ This prohibition raises more serious

82. Kan. StaT. ANN. § 72-64b03(a)-(b) (Supp. 2016) (directing that, after notification that a civil action "alleging a violation of article 6 of the Kansas constitution" had been filed, the chief judge of the Kansas Court of Appeals "shall appoint a panel of three current or retired district court judges to preside over such civil action").

83. If the legislators thought that a three-judge panel would be more receptive to the legislature's position or reluctant to find that the legislature had failed to fulfill its constitutional duty to fund schools adequately, Gannon suggests that was a mistake. The three-judge panel issued two decisions, both of which were highly critical of the legislature and both of which found constitutional violations that required substantial additional funding. The first decision of the threejudge panel in Gannon v. State in 2013 made numerous findings against the state and required substantial additional funding to be provided. No. 10C1569, 2013 WL 146092, at *88-89 (Kan. Dist. Ct. Jan. 10, 2013). That decision was reversed in part by the Kansas Supreme Court, which clarified the standards for determining the adequacy of funding and remanded to the panel for reconsideration in light of those standards. See Gannon v. State (Gannon I), 319 P.3d 1196, 121624 (Kan. 2014). After remand, the panel reaffirmed its original conclusion that the legislature had failed to provide adequate funding. See Gannon v. State, No. 2010CV1569, ShawneE Ct. (Kan. Dist. Ct. Dec. 30, 2014), http://www.shawneecourt.org/DocumentCenter/View/527.

84. Indeed, for many years, federal law provided for certain categories of cases to be tried before three-judge district court panels. See generally Leland C. Nielsen, Three-Judge Courts: A Comprehensive Study, 66 F.R.D. 495 (1975) (discussing the use of three-judge panels in the federal court system).

85. See Gannon, 2013 WL 146092, at *1.

86. There are two virtually identical statutory provisions: one for the three-judge panel and one for appellate courts. See KAN. STAT. ANN. § 72-64b03(d) (Supp. 2016) (“As a part of a remedy, preliminary decision or final decision in which a statute... has been held unconstitutional as a violation of article 6 of the Kansas constitution, the judicial panel ... shall not have the authority to order a school district ... to be closed or enjoin the use of all statutes related to the distribution of funds for public education.”); KAN. STAT. ANN. § 60-2106(d) (Supp. 2016) (“As a part of a remedy, 
constitutional questions because it purports to limit the courts' remedial authority and thereby may encroach on their authority in a manner that violates separation of powers. It is important to bear in mind that it was the threat of closing the schools that ultimately forced the legislature to provide funding in Montoy. ${ }^{87}$ Prohibiting this remedy was thus an obvious effort to deprive the courts of their most powerful tool to ensure compliance with school finance orders. The plaintiffs in Gannon argued that the prohibition was unconstitutional, but the three-judge panel avoided the question, concluding that the issue was not ripe because there was a better remedy available. ${ }^{88}$

The Kansas Supreme Court also has avoided addressing the constitutionality of this prohibition, but it has sent signals suggesting that it will not accept such a limit on its powers. Given the court's resolution of the first appeal in Gannon, which entailed a remand to the panel for further findings, it was unnecessary to address any remedial issues. ${ }^{89}$ The appeal after remand was bifurcated into an equity and an adequacy component, and the equity component was further along in the process because there was no need for new findings after remand on that issue. In Gannon v. State (Gannon II), the Kansas Supreme Court affirmed the panel's finding that the failure to fully fund state equalization aid (which compensated for differentials in local tax bases) violated the requirement of equity in school finance. ${ }^{90}$ Because the court ultimately chose not to impose a remedy-giving the legislature a chance to correct the deficiency first - it was again unnecessary for the court to determine the validity of the provisions limiting the courts' remedial authority in school finance cases. ${ }^{91}$

Nonetheless, after determining that the legislature had failed to meet its constitutional duty to provide equitable funding for schools, the Kansas Supreme Court engaged in a lengthy explanation of the courts' duty to enforce the constitution as superior law and their corresponding

preliminary decision or final decision in which a statute... has been held unconstitutional as a violation of article 6 of the Kansas constitution, the appellate court . . shall not have the authority to order a school district... district to be closed or enjoin the use of all statutes related to the distribution of funds for public education.").

87. See supra notes $18-22$ and accompanying text.

88. Gannon, 2013 WL 146092, at $* 80$. The panel instead issued an injunction directing the state to comply with the school finance laws already on the books. Id. at *87-88.

89. Gannon v. State (Gannon I), 319 P.3d 1196, 1251 ("Because we are reversing and remanding, which may eventually make the remedy issues moot, we reach no decision on any particular arguments in the remedy context.").

90. 368 P.3d 1024, 1060-62 (Kan. 2016).

91. Id. 
power to impose remedies for constitutional violations. ${ }^{92}$ And the court left little doubt what the remedy would be if the legislature failed to meet its constitutional obligations: "Without a constitutionally equitable school finance system, the schools in Kansas will be unable to operate beyond June 30. And because an unconstitutional system is invalid, efforts to implement it can be enjoined." Gannon II did not cite or discuss the statutory provisions purporting to prohibit this remedy (at least I did not discover any such reference), suggesting that the court regarded them as null and void. ${ }^{94}$

Second, the Kansas Supreme Court invalidated the statutory provisions divesting it of authority to appoint chief judges in each district, notwithstanding the legislature's actions to link that provision to the judiciary's budget. Traditionally, the appointment of chief judges of the district courts had been the responsibility of the Kansas Supreme Court, consistent with its administrative responsibility for the judicial system under the Kansas Constitution. ${ }^{95}$ In the 2014 session, however, the legislature added a provision to the appropriations bill for the judiciary amending chapter 20, section 329 of the Kansas Statutes Annotated to specify that "[i]n every judicial district, the district court judges in such judicial district shall elect a district judge as chief judge ...."96 Although there might have been some policy justifications

\footnotetext{
92. Id. at $1056-60$.

93. Id. at 1062 ("[T]he legislature's chosen path during the 2016 session will ultimately determine whether Kansas students will be treated fairly and the schoolhouse doors will be open to them in August for the beginning of the 2016-2017 school year."); see also Gannon v. State (Gannon IV), No. 113,267, 2017 WL 833551, at*41(Kan. Mar. 2, 2017) ("[I]f by June 30, 2017, the State has not satisfactorily demonstrated to this court that any $\mathrm{K}-12$ public education financing system the legislature enacts is capable of meeting the adequacy requirements of Article 6, then a lifting of the stay of today's mandate will mean that the state's education financing system is constitutionally invalid and therefore void.").

94. The legislative response to the equity portion of the litigation during the 2016 legislative session did not entirely satisfy the court, which nonetheless delayed imposing any remedial order so as to give the legislature an opportunity to comply. See Gannon v. State (Gannon III), 372 P.3d 1181, 1204 (Kan. 2016). A special legislative session resulted in corrective legislation, and the parties subsequently stipulated as to legislative compliance. See Joint Stipulation of Constitutionally Equitable Compliance, Gannon v. State, No. 15-113,267-S, KAN. CTS. 2 (Kan. June 27, 2016), http://www.kscourts.org/kansas-courts/supreme-

court/Cases_of_interest/Cases/113267/JointStipulationConstitutionallyEquitbleCompliance.pdf. The adequacy portion of the case, however, may test the limits of the courts' remedial authority.

95. See KAn. CONST. art. 3, § 1 ("The supreme court shall have general administrative authority over all courts in this state."). The power to appoint chief judges was originally asserted by Supreme Court Rule, which was later codified into statute. See Solomon v. State, 364 P.3d 536, 540-41 (Kan. 2015).

96. KAN. Stat. ANN. § 20-329 (Supp. 2016); S. Substitute for H.B. 2338, 2014 Leg. Sess. § (Kan. 2014), http://kslegislature.org/li_2014/b2013_14/measures/documents/hb2338_enrolled.pdf.
} 11 
for this amendment, none were evident and the measure was widely perceived as a rebuke of the Kansas Supreme Court, which was the focus of considerable legislative ire at the time.

Standing alone, this sort of measure does not represent a substantial threat to the decisional independence of the judiciary, regardless of its impact on judicial administration. ${ }^{97}$ But the legislature sought to protect the amendment against any constitutional challenge by incorporating a non-severability clause into the law. This clause specified that "[i]f any provision of this act is stayed or is held to be invalid or unconstitutional, it shall be presumed conclusively that the legislature would not have enacted the remainder of such act without such stayed, invalid or unconstitutional provision." " 98 In other words, if the courts stuck down the provision divesting the Kansas Supreme Court of authority to appoint the chief judge of each district, then the entire appropriation for the judiciary would be invalid.

In practice, then, the non-severability clause threatened the judiciary with a loss of funding if it did not uphold the legislature's attempt to divest the Kansas Supreme Court of this administrative authority. ${ }^{99}$ The constitutionality of this sort of threat is open to doubt, and one option for the courts might have been to invalidate it ${ }^{100}$ or to conclude that it was not controlling. ${ }^{101}$ That sort of funding condition, if valid, is a severe threat to judicial independence, and could be in an effort to insulate

97. It focuses on a relatively minor aspect of the administration of the courts, because being named the chief judge of a district does not bring with it a lot of power. Moreover, it leaves control over this matter within the judiciary itself. Nonetheless, government officials often care deeply about preserving and/or expanding their institutional authority, so stripping the supreme court of this sort of administrative power may be an effective form of punishment for unpopular decisions.

98. S. Substitute for H.B. $2338 \S 43$. A similar provision was added to the judicial appropriations bill adopted in 2015, which took the unusual step of treating the provision in the 2014 legislation as not severable from the subsequent year's budget. See H.B. 2005, 2015 Leg. Sess. § 29 (Kan. 2015), http://kslegislature.org/li_2016/b2015_16/measures/documents/hb2005_enrolled.pdf ("Except as provided further, the provisions of this act are not severable, nor are they severable from the provisions of 2014 Senate Substitute for House Bill No. 2338, chapter 82 of the 2014 Session Laws of Kansas.").

99. See generally Russell Berman, The Court Case That Could Shut Down Kansas's Courts, ATLANTIC (Sept. 5, 2015), https://www.theatlantic.com/politics/archive/2015/09/the-court-case-thatcould-shut-down-kansass-courts/403957/.

100. See Stilp v. Commonwealth, 905 A.2d 918, 980 (Pa. 2006) (holding that a non-severability clause inserted into bill providing for judicial compensation was invalid because "enforcement of the clause would intrude upon the independence of the Judiciary and impair the judicial function").

101. See e.g., Gannon v. State (Gannon III), 372 P.3d 1181, 1198-1203 (Kan. 2016) (discussing why the court chose to disregard a statute's severability clause). Courts often invalidate statutes based on one invalid provision notwithstanding severability clauses, which legislatures typically insert as boilerplate language. See id. at 1200. Instead, courts exercise their independent judgment to determine the ultimate question - whether the legislation would have passed without the invalid provision. See id. at 1201-03. 
virtually any legislative action from a constitutional challenge. The Kansas Supreme Court, however, did not blink.

In Solomon v. State, the Kansas Supreme Court held that chapter 20, section 329 of the Kansas Statutes Annotated violated separation of powers by infringing upon the power to administer the courts, which Article 3, section 1 vests in the Kansas Supreme Court. ${ }^{102}$ The court focused on the purpose of this constitutional provision, adopted in 1972, which was to establish "clear lines of responsibility and authority in the administration of district courts ultimately leading back to the Supreme Court." " 103 The court then concluded that the statute violated the wellestablished four-part separation of powers test under which courts consider: "(1) the essential nature of the power being exercised; (2) the degree of control by one branch over another; (3) the objective sought to be attained; and (4) the practical result of blending powers as shown by actual experience over a period of time." 104

The court thus invalidated the law notwithstanding the apparent impact of that decision on the judiciary's budget, but it did not address the validity of the non-severability clause. Instead, the court observed:

[W]e note that the district court relied on sec. 43 of H.B. 2338, a nonseverability clause, to strike the legislation in its entirety. Neither party has challenged the validity of that portion of the district court ruling, and we accordingly do not address it here. We note only that our holding appears to have practical adverse consequences to the

102. See 364 P.3d 536, 544, 549-50 (Kan. 2015). It is interesting to note that Justice Stegall also thought that this provision was unconstitutional, although he disagreed with the majority's reasoning. Id. at 550-57 (Stegall, J., concurring). Justice Stegall advocated instead for a return to the approach articulated in State ex rel. Godard v. Johnson, which stated, "the functions of the three departments should be kept as distinct and separate as possible." Id. at 556 (quoting State ex rel. Godard v. Johnson, 60 P. 1068, 1072 (Kan. 1900)). Under this approach, when "the Government is called upon to perform a function that requires an exercise of legislative, executive, or judicial power, only the vested recipient of that power can perform it." Id. (quoting Dep't of Transp. v. Ass'n of Am. R.Rs., 135 S. Ct. 1225, 1241 (2015) (Thomas, J., concurring)).

103. Id. at 544 (majority opinion).

104. Id. at 546 (citing, inter alia, Miller v. Johnson, 289 P.3d 1098, 1122 (Kan. 2012)). Applying these factors, the court reasoned that the provision was unconstitutional. See id. at 54648. First, the selection and supervision of chief judges was, by its essential nature, a judicial function. Id. at 546-47. Second, "[t]he intervention by the legislature in 2014 would result in removal from the Supreme Court of an essential component of its constitutionally mandated administrative authority." Id. at 547. The third factor, which the court described as "the least important" (because a good purpose would not save an otherwise invalid law), also cut against the validity of the amendment because the stated goal of promoting local control over each district was directly contrary to the purposes of the 1972 constitutional amendment. Id. (internal quotations omitted). Finally, the fourth factor was difficult to apply because there was no experience in Kansas with this method of selecting the chief judges of judicial districts. Id. 
judiciary budget, which the legislature may wish to address, even though those concerns played no part in our analysis. ${ }^{105}$

Rather than provoking a direct confrontation by invalidating or ignoring the non-severability clause, the Supreme Court accepted it (without resolving its validity). This result forced the legislature to decide whether it really wanted to defund the courts, which serve a variety of essential public functions. Whatever the legislature's dissatisfaction with particular decisions might be, defunding the courts would have had profound negative consequences for the state and was never really a viable option. Accordingly, the legislature acted promptly to restore judicial funding after the Solomon decision. ${ }^{106}$

A final, less high-profile example of legislative action targeting the courts was a statutory provision imposing deadlines for the issuance of judicial decisions. Under chapter 20, section 3301 of the Kansas Statutes Annotated, if a court fails to issue a decision within a specified statutory deadline, counsel for all parties must submit a joint request to the court for a decision without further delay, at which point the court must either issue a decision within 30 days or advise the parties of the date on which the decision will be issued. ${ }^{107}$ While delays in issuing decisions are frustrating for parties, may deny or defer restorative justice to injured persons, and should be minimized if possible, the imposition of statutory deadlines arguably interferes with the judicial decision-making process.

In State v. Buser, the Kansas Supreme Court held that the statute violated separation of powers. ${ }^{108}$ The case came before the court in an unusual procedural posture, as attorneys in a pending case sought a judicial order relieving them of the obligation to file a request pursuant to the statute, arguing it would violate their professional obligations as attorneys to file such a plainly unconstitutional request. ${ }^{109}$ The Kansas Supreme Court agreed, relying on State ex rel. Morrison v. Sebelius, which had held that the Attorney General was not required to comply with a statutory directive to file a lawsuit seeking an advisory opinion,

\footnotetext{
105. Id. at 550 .

106. See, e.g., Jonathan Shorman, Kansas Lawmakers Send Judicial Funding Fix to Governor, TOPEKA CAP.-J., http://cjonline.com/news/2016-01-28/kansas-lawmakers-send-judicial-funding-fixgovernor (last updated Jan. 29, 2016).

107. Under this statute, which was adopted in the 2014 legislative session, trial judges would have 120 days to render a decision upon submission of a matter, and both the Kansas Court of Appeals and the Kansas Supreme Court were required to file a decision within 180 days. KAN. StAT. ANN. § 20-3301 (Supp. 2016), invalidated by State v. Buser, 302 Kan. 1, 14, 2015 WL 4646663 , at *10 (2015).

108. Buser, 302 Kan. at 14, 2015 WL 4646663 , at *10.

109. Id. at $3,2015 \mathrm{WL} 4646663$, at $* 2$.
} 
which he regarded as a clear violation of separation of powers. ${ }^{110}$ Applying the four-factor test from Miller v. Johnson, ${ }^{111}$ the court concluded that the provision at issue in Buser encroached upon the judicial power in violation of separation-of-powers principles. ${ }^{112}$

While the courts have rebuffed these legislative challenges to their power and discretion, at least for the time being, the extent to which they can rely on the political branches to comply with and enforce controversial orders remains an open question in the present political climate. Ultimately, the courts are without power to enforce their own orders and there may be little that they can do if both the legislature and the executive branch choose to defy their decisions. In such a case, only public support for the rule of law could force their hands.

\section{LETTER FIVE: BACK TO SCHOOLS}

Dear Readers:

As noted in my last letter, the ultimate test for judicial independence and the rule of law may be whether the political branches comply with and enforce judicial orders with which they disagree. This has been a particular issue in the context of school finance litigation, as judicial decisions in Kansas and in other states finding that school funding is constitutionally inadequate have often faced legislative delays, resistance, and noncompliance. ${ }^{113}$ The particular difficulty for the courts

110. Id. at 14, $2015 \mathrm{WL} 4646663$, at *10 ("Subsections (c)(1), (2), and (3) violate the separation of powers doctrine under the rationale expressed in Sebelius ...."); State ex rel. Morrison v. Sebelius, 179 P.3d 366, 392-93 (Kan. 2008).

111. See supra note 104 and accompanying text.

112. See Buser, 302 Kan. at 6-14, 2015 WL 4646663, at *5-10 (analyzing the statutory deadline and the mandatory attorney request requirement separately). First, "[t]he power to determine when a court renders its decisions is essential to the basic judicial power 'to hear, consider and determine controversies between rival litigants." Id. at 8, $2015 \mathrm{WL} 4646663$, at *6 (quoting Sebelius, 179 P.3d 366, 382 (Kan. 2008) (citations omitted)). Second, both the thirty-day deadline and the requirement to set a date for issuance of the opinion involved excessive control by the legislature over the judiciary. Id. at 10-13, $2015 \mathrm{WL} 4646663$, at *7-9. This conclusion was relatively straightforward respecting the mandatory thirty-day deadline. Id. at $8-9,2015 \mathrm{WL}$ 4646663, at*6-7. The conclusion was more complicated as to the second option, which left the date up to the court, but this requirement nonetheless imposed a mandatory requirement that interfered with the courts' ability to take the time needed to render a sound decision. Id. at 10-13, $2015 \mathrm{WL}$ 4646663 , at $* 8-9$ (analyzing the first and second Miller factors together). As to the third factor, the legislature's goal of ensuring prompt judicial resolution of cases was laudable, and one shared by the court, but it could not be achieved through means that violated the separation of powers. Id. at 9-10, 2015 WL 4646663, at*7 (statutory deadline); id. at 13, 2015 WL 4646663, at *9 (attorney request). Finally, because the statute was a novel one, there was no practical experience to draw on and the fourth factor was indeterminate. Id. at 10, $2015 \mathrm{WL} 4646663$, at *7 (statutory deadline); $i d$. at 13, 2015 WL 4646663, at *10 (attorney request).

113. See Gunfight at the K-12 Corral, supra note 18, at 1078-93 (discussing remedial issues in 
in this context is that the remedy for a constitutional violation is to provide more money for schools.

It is, of course, true that raising revenue, appropriating funds, and establishing the state's budget are matters for the legislature. But the Constitution limits the legislature's powers in these areas in various ways, including a balanced budget requirement. ${ }^{114}$ Insofar as the Constitution is the superior law, limitations on the legislature's fiscal powers are binding and the rule of law contemplates that they are judicially enforceable. Like the balanced budget requirement, the people of the state of Kansas adopted Article 6 of the Kansas Constitution, which specifies that the legislature "shall provide for intellectual, educational, vocational and scientific improvement by establishing and maintaining public schools" and that it "shall make suitable provision for finance of the educational interests of the state." 115 These provisions establish a constitutional budget priority for funding the schools that overrides political considerations.

On March 2, 2017, while this essay was in process, the Kansas Supreme Court issued its latest ruling in Gannon v. State (Gannon IV). ${ }^{116}$ As expected, the court affirmed the panel's conclusion that the legislature had failed to provide adequate funding for the schools. ${ }^{117}$ Nonetheless, the court acceded to the state's request to "issue a declaratory judgment with guidance for the Legislature while at the same time allowing the Legislature both the flexibility and an opportunity to revise the school finance system." for legislative action: June 30, 2017. ${ }^{119}$ We are, in a sense, back where we started.

school finance cases).

114. See KAN. CONST. art. 11, § 4 ("The legislature shall provide, at each regular session, for raising sufficient revenue to defray the current expenses of the state for two years."); see also id. at $\S \S 6-7$ (limiting indebtedness).

115. KAN. CONST. art. $6, \S \S 1,6(\mathrm{~b})$.

116. No. 113,267, 2017 WL 833551 (Kan. Mar. 2, 2017).

117. Id. at $* 24-39$ (concluding that the structure and implementation of current school finance laws violated Article 6 based on a review of both inputs and educational outcomes).

118. Id. at $* 40$

119. Id. at *41 ("So if by June 30,2017 , the State has not satisfactorily demonstrated to this court that any $\mathrm{K}-12$ public education financing system the legislature enacts is capable of meeting the adequacy requirements of Article 6, then a lifting of the stay of today's mandate will mean that the state's education financing system is constitutionally invalid and therefore void.") (citations omitted). The court did not specify a dollar amount that would be needed to comply, but estimates place the figure at somewhere between $\$ 500$ and $\$ 800$ million dollars. See Bryan Lowry, Hunter Woodall, \& Katy Bergen, Kansas Supreme Court Rules the State Has Failed to Ensure Adequate Education Funding, KAN. CITY STAR (Mar. 2, 2017), http://www.kansascity.com/news/politicsgovernment/article135949108.html (noting that "John Robb, an attorney for the plaintiff districts, 
It is unclear what the legislative response to the court's decision will be. Initial legislative reactions have been "muted," with few expressions of outrage or calls for defiance. ${ }^{120}$ This response, which contrasts with the outcry during the last round of school finance litigation, may be attributable to several factors. Legislators apparently appreciated the court's willingness to give the legislature a chance to remedy the deficiency and the court's decision not to specify a dollar amount needed to satisfy its mandate. ${ }^{121}$ Another factor may be that the ruling was expected; legislators have long anticipated the need to come up with additional money for schools. But I think the results of the retention election are also significant. The rejection of efforts to unseat the four targeted justices represents, in effect, a public endorsement of the court's role in enforcing Article 6 of the Kansas Constitution.

Nonetheless, the potential for renewed conflict between the political branches and the court over school finance remains high. ${ }^{122}$ Given the state's current budgetary shortfalls, it will not be easy to come up with the necessary additional funds. ${ }^{123}$ As of this writing, the legislature has

pegged the cost of doing this at roughly $\$ 800$ million," while "Dale Dennis, the director of school finance for the Kansas Department of Education, said that the cost would be closer to $\$ 535$ million"). These estimates are consistent with those that surfaced after the panel decision. See Dion Lefler \& Bryan Lowry, District Court Panel: School Funding Inadequate Under Kansas Constitution, Wichita EAGLE (Dec. 30, http://www.kansas.com/news/local/education/article5169564.html (reporting estimates that increases in base state aid per pupil and other funding factors would require somewhere between $\$ 548$ million and $\$ 771$ million per year).

120. See Peter Hancock, School Finance Ruling Has Democrats Ecstatic; Brownback Uses It to Tout Need for School Choice, LAWRENCE J. WORLD (Mar. 2, 2017), http://www2.ljworld.com/news/2017/mar/02/court-ruling-leaves-some-state-local-officials-spe/ (contrasting "muted" response to Gannon decision with legislative reaction to the Montoy decision).

121. See id.

122. In this regard, it is important to bear in mind that the court's first adequacy decision in Montoy took a similar approach and the legislature did respond by appropriating additional funds. Matters did not come to a head until the Kansas Supreme Court rejected that effort as insufficient to cure the constitutional defect and made clear the magnitude of additional funding that would be needed. See Gunfight at the K-12 Corral, supra note 18, at 1044-47. One sign that compliance may become contentious is the legislature's decision to hire former Senator Jeff King to advise it on compliance with the order. See, e.g., Celia Llopis-Jepsen, Kansas Legislature Hires Former Senator Jeff King as Attorney on School Funding, over Democratic Objections, TOPEKA CAPITAL-JOURNAL (Apr. 7, 2017), http://cjonline.com/news/state-government/2017-04-07/kansas-legislature-hiresformer-senator-jeff-king-attorney-school. Although legislative leaders and Senator King insist that he was hired for his legal expertise rather than his political expertise, it is significant that Senator King has been an outspoken critic of the Kansas Supreme Court and a leading proponent of the block grant measure rejected by the court in Gannon $I V$, as well as the non-severability clause discussed earlier. Id.; supra notes 97-106 and accompanying text.

123. See, e.g., Hunter Woodall, Kansas Expects Budget Shortfall Around \$350 Million This Fiscal Year, KAN. CITY STAR (Nov. 10, 2016), http://www.kansascity.com/news/politicsgovernment/article114021098.html (noting recent budgetary issues that Kansas is facing). 
not been able to come up with a plan to address existing shortfalls, much less find an additional half a million dollars a year (or more) for schools. ${ }^{124}$ Given these political realities, there is a distinct possibility that the legislature will not be able to agree on a response to the court's decision or that the legislative response will be insufficient to satisfy the court. $^{125}$

If the necessary funding is not forthcoming, it is not clear what the court can, should, or will do in response. Unlike most constitutional provisions, the judiciary cannot remedy a violation of Article 6 by enjoining the operation of or invalidating unconstitutional state laws. Curing constitutionally inadequate funding levels requires legislation appropriating additional funding. State courts have tried various solutions to this remedial problem, ${ }^{126}$ including a recent order in Washington finding the state in contempt for persistent failure to correct deficiencies in school funding and ordering the state to pay a fine of $\$ 100,000$ per day into an escrow account for the schools. ${ }^{127}$ One suspects that the Kansas Legislature would not prefer this remedy to the one used in Montoy and foreshadowed in Gannon II: enjoining the

124. Although the legislature passed a bill repealing many of the tax cuts enacted in 2011, see supra note 25 and accompanying text, Governor Brownback vetoed the bill, and there were insufficient votes in the Senate to override it. Hunter Woodall \& Bryan Lowry, Gov. Sam Brownback's Tax Policies Survive - Barely - After Kansas Senate Vote, KAN. CiTy STAR (Feb. 22, 2017), http://www.kansascity.com/news/politics-government/article134334184.html.

125. If so, the court is not likely to be sympathetic to legislative claims that the money to comply with a judicial order is simply not available. See Gannon v. State (Gannon III), 372 P.3d 1181, 1198 (Kan. 2016) (acknowledging "the political realities of the legislative branch" but concluding that "we must review lawmakers' efforts for conformity with the Kansas Constitution"). The issue is further complicated by the need to develop a new funding formula to replace the system of block grants that was adopted while the appeal was pending in Gannon. See Gannon v. State (Gannon II), 368 P.3d 1024, 1041 (Kan. 2016) (concluding that the block grant system was "a mere extension of the fiscal year 2015 funding system" that "is not a substantial shift in the way funds are distributed for public education" because block grants were "calculated primarily using the nowrepealed SDFQPA formula").

126. See Gunfight at the K-12 Corral, supra note 18, at 1089-93 (discussing states' remedial approaches).

127. McCleary v. State, No. 84362-7, WASH. CTS. 8-10 (Wash. Aug. 13, 2015), http://www.courts.wa.gov/content/publicUpload/Supreme\%20Court\%20News/843627_081315McCl earyorder.pdf. See also Joseph O’Sullivan, Jim Brunner \& Paige Cornwell, School Funding Back on Table as Court Fines State \$100,000 a Day, SEATTLE TimES (Aug. 13, 2015), http:/www.seattletimes.com/seattle-news/education/supreme-court-orders-100000-per-day-fines-inmccleary-case/. On October 6, 2016, the Washington Supreme Court rejected the state's argument that legislative action had cured the constitutional deficiencies and continued the contempt sanction in place. McCleary v. State, No. 84362-7, WASH. CTS. 8-13 (Wash. Oct. 6, 2016), http://www.courts.wa.gov/content/publicUpload/Supreme\%20Court\%20News/843627Order100616. pdf. 
expenditure of funds pursuant to constitutionally invalid spending provisions. ${ }^{128}$

But either remedy would depend on the executive branch to be effective. ${ }^{129}$ If, for example, the Kansas Supreme Court ruled the statutory prohibition on enjoining the expenditure of funds for schools invalid and issued an injunction, would the responsible officials in the executive branch comply with the order? There were voices counseling defiance in response to the court's orders in the Montoy litigation, although the legislature ultimately complied.

I certainly hope that the conflict between the judiciary and the political branches does not lead to open defiance. If it does come to that, the power of the courts will ultimately depend on how much the people of the state care about the rule of law.

128. As noted previously, although statutes purport to preclude the courts from enjoining school funding, those statutes are arguably unconstitutional and the court does not seem to be deterred by them. See supra notes 86-94 and accompanying text.

129. For example, it is not clear what the Washington Supreme Court could or would do if state officials did not pay the fine as required by its orders. 